JURNAL RISET PENDIDIKAN MATEMATIKA

Volume 3 - Nomor 1, Mei 2016, (122 - 136)

Available online at http://journal.uny.ac.id/index.php/jrpm

\title{
PENINGKATAN MOTIVASI DAN KETERAMPILAN HITUNG PECAHAN DESIMAL MELALUI MEDIA MANIPULATIF PADA PEMBELAJARAN TEMATIK-INTEGRATIF SD
}

\author{
Yuni Ristanti \\ SD Negeri 15 Ulu Gadut, Jalan Raya Ulu Gadut, Limau Manis Selatan, Pauh, Padang, Indonesia \\ Korespondensi Penulis. Email: yuniristanti@gmail.com, Telp: +6281374971643 \\ Received: 15 $5^{\text {th }}$ June 2016; Revised: 12 $2^{\text {th }}$ July 2016; Accepted: $6^{\text {th }}$ September 2016
}

\begin{abstract}
Abstrak
Penelitian ini bertujuan untuk: (1) mengetahui apakah penampilan guru dalam mengajar berada pada klasifikasi baik untuk mendukung peningkatan keterampilan hitung dan motivasi belajar, (2) meningkatkan motivasi belajar siswa, dan (3) meningkatkan keterampilan hitung pecahan desimal siswa kelas 4 SDN 15 Ulu Gadut (Padang) melalui media manipulatif pada pembelajaran tematik integratif dengan menggunakan desain penelitian tindakan kelas. Teknik pengumpulan data menggunakan: observasi, tes tskala motivasi, catatan lapangan, dan tes kemampuan hitung. Analisis data dilakukan secara kualitatif dan kuantitatif. Hasil penelitian menunjukan: (1) penampilan guru dalam mengajar memperoleh skor 160,5; 174; dan 179,17 dengan klasifikasi baik pada siklus 1, 2, dan 3. (2) motivasi peserta didik meningkat dari siklus 1,2 , dan 3 berturut-turut senilai $62,04,65,56$, dan 68,16 sedangkan hasil tes skala motivasi meningkat dengan skor pada siklus 1, 2, dan 3 senilai 79,41, 85,05, dan 87,05. (3) Hasil tes keterampilan hitung siklus 3 memperoleh skor 90,81 pada level I, 93,51 pada level II, 75,14 pada level III, 75,68 pada level IV, dan 76,76 pada level V.
\end{abstract}

Kata Kunci: keterampilan hitung pecahan desimal, motivasi belajar, media manipulatif, tematikintegratif.

\section{IMPROVING MOTIVATION AND THE DECIMAL COMPUTATION SKILL BY USING MANIPULATIVES IN THEMATIC-INTEGRATED LEARNING IN ELEMENTARY SCHOOL}

\begin{abstract}
This study aims to: (1) determine whether teacher's performance in teaching using manipulatives media are in good classification to support arithmetic skills and students' learning motivation (2) increase the learning motivation, and (3) increase the decimal computation skill of class IV B students of SDN 15 Ulu Gadut, Padang by using manipulatives. The results are as follows: (1) the teacher's teaching performance is in a good category with a total score of cycles I, II, and III, 160.5, 174, and 179.17 respectively. (2) the students' learning motivation has increased by 62.04 in cycle I, 65.56 in cycle II, and 68.16 in cycle III and then, the result of students' motivation scale test is in a very high category, with an average increase of 79.41, 85.05, and 87.05 in cycles I, II, III. (3) the results of arithmetic skill test at the end of the third cycle are at an average score of 90.81 at level I, 93.51 at level II, 75.14 at level III, 75.68 at level IV, and 76.76 at level V.
\end{abstract}

Keywords: decimal computation skill, learning motivation, manipulatives, thematic integrated.

How to Cite: Ristanti, Y. (2016). Peningkatan motivasi dan keterampilan hitung pecahan desimal melalui media manipulatif pada pembelajaran tematik-integratif SD. Jurnal Riset Pendidikan Matematika, 3(1), 122-136. doi:http://dx.doi.org/10.21831/jrpm.v3i1.9686

Permalink/ DOI: http://dx.doi.org/10.21831/jrpm.v3i1.9686 


\section{PENDAHULUAN}

Undang-undang Nomor 20 tahun 2003 tentang Sistem Pendidikan Nasional menyatakan bahwa kurikulum pada jenjang pendidikan dasar dan menengah wajib memuat mata pelajaran matematika. Salah satu kompetensi dalam muat-an matematika pada tingkat kelas III dan IV dalam Peraturan Menteri Pendidikan dan Kebudayaan nomor 64 tahun 2013 tentang Standar Isi Pendidikan Dasar dan Menengah adalah menunjukkan sikap positif bermatematika diantaranya sikap tidak mudah menyerah dalam menyelesaikan masalah, sebagai wujud implementasi kebiasaan dalam inkuiri dan eksplorasi matematika.

Kompetensi dalam muatan matematika tingkat kelas III dan IV pada permendikbud nomor 64 tahun 2013 menyatakan agar peserta didik dapat menyelesaikan masalah aritmetika sehari-hari sebagai penerapan pemahaman atas efek penambahan dan pengurangan. Materi pecahan desimal pada peserta didik kelas IV sesuai dengan Permendikbud nomor 67 adalah materi tentang pengubahan pecahan ke bentuk desimal dan persen pada semester I dan penjumlahan dan pengurangan bilangan desimal pada semester II.

Permasalahan yang paling mendasar yang dihadapi peserta didik kelas IV B SDN 15 Ulu Gadut pada penjumlahan dan pengurangan pecahan desimal adalah belum memahami konsep nilai tempat pada bilangan desimal, sehingga peserta didik mengalami kesulitan saat menjumlahkan atau mengurangkan bilangan desimal dengan jumlah angka di belakang koma yang berbeda dan mengurangi dengan bilangan nol. Kebanyakan peserta didik hanya menuliskan bilangan yang mengurangi dengan nol (misalnya 10,04 dikurangi 0,41 jawaban mereka adalah 10,43) dan cenderung "lupa" bahwa bilangan telah dipinjam. Kesalahan-kesalahan ini terjadi karena peserta didik belum paham bahwa dalam satu ratusan terdapat sepuluh puluhan dan belum memahami konsep nilai tempat terutama pada nilai tempat pecahan desimal yang termasuk dalam konsep yang abstrak.

Teori perkembangan Piaget menyatakan bahwa peserta didik kelas empat sekolah dasar berada dalam tahapan operasional konkret membutuhkan benda nyata untuk dapat memahami konsep. Guru perlu mengajar menggunakan alat peraga berupa benda nyata agar peserta didik memahami konsep pembelajaran matematika dan termotivasi dalam mengikuti pelajaran.
The Common Core State Standard (Burns, 2013, p.1) menyatakan bahwa model benda kongkret merupakan alat penting untuk belajar matematika pada semua tingkatan kelas dan menyarankan penggunaan model secara teratur pada langkah-langkah awal peserta didik belajar matematika sebelum pindah ke representasi lain. D'Augustine \& Smith (1992, p.255) menganjurkan penggunaan model manipulatif berbentuk persegi untuk membelajarkan pecahan desimal. Model manipulatif tersebut berupa model yang menunjukkan pecahan persepuluhan dan pecahan perseratusan yang dapat membuat peserta didik memahami nilai tempat pada bilangan desimal. Hal tersebut dilakukan untuk membantu peserta didik memahami konsep bilangan pecahan desimal yang bersifat abstrak. Peserta didik kelas IV B di Sekolah Dasar Negeri (SDN) No. 15 Ulu Gadut mengalami kesulitan dalam menjumlahkan dan mengurangi bilangan desimal mengenai bilangan yang tidak diketahui. Alternatif untuk memperbaiki proses pembelajaran tesebut dengan menggunakan media manipulatif.

The National Bussiness Education Association (Blaszczysnky \& James, 2001, p.19) menekankan pentingnya keterampilan hitung bagi peserta didik dengan memberikan karena sebagai warga negara suatu saat akan membutuhkan keterampilan hitung ketika akan membuat keputusan. Carroll (1996, p.305) mengatakan "...use of mental computation is motivating for many students" Baturo, Nason, \& Hatfield, et al. (McCarthy, 2007, p.24), "conceptual knowledge or conceptual understanding is the ability to make sense of mathematical meanings underlying concepts and procedures". Pendapat tersebut dipertegas McCharty dengan mengutip pernyataan The Principles and Standards for School Mathematics (NCTM, 2000, p.20) menyatakan, "students must learn mathematics with understanding, actively build new knowledge from experience and prior knowledge".

Witzel, Ferguson, \& Mink (2012, p.90) menyatakan, "it is difficult for children to understand the concept of regrouping (borrowing and carrying) in addition and substraction if they learn how to regroup using step-by-step procedures; they must also understand why they are performing these steps".

Disisi lain, motivasi juga merupakan faktor penting dalam belajar. Brewer \& Burgess (Nilsen, 2009, p.546) menyatakan, "motivation is identified as a fundamental aspect of learn- 
ing”. Pendapat Ryan \& Deci (Nilsen, 2009, p.546) tentang motivasi adalah, "but what is motivation really, how do I know I am motivated? To be motivated means to be moved to do something”. Crump (Nilsen, 2009, p.546) menjelaskan komponen utama dari motivasi pembelajaran dengan menyatakan kegembiraan, minat, dan antusiasme terhadap pembelajaran adalah komponen utama dari motivasi. Berdasarkan pendapat ketiga ahli dalam Nilsen tersebut dapat dipahami bahwa motivasi belajar merupakan aspek fundamental dari pembelajaran yang membuat peserta didik melakukan sesuatu tindakan dengan memiliki kegembiraan, minat, dan antusiasme terhadap pembelajaran.

Mengenai pecahan desimal, Souviney (1994, p.434) menyatakan, "the term decimal is based on the Latin word deci, meaning ten. Decimals are simply fraction that are written with power of 10 as denominators $\left(\frac{1}{10}, \frac{1}{100}\right.$, etc)". Hiebert (Mun Yee Lai \& Kin Wai Tsang, 2009, p.2), "decimal numbers are number that can be represented by case-10 numeral with digits to the right as well the left of the decimal point". Hiebert memberikan pendapat bahwa sistem bilangan desimal dapat digolongkan menjadi tiga prinsip, yaitu: "principle 1: the value of a digit is a function of its position in the numeral".

Prinsip kedua yang dikemukakan oleh Hiebert yaitu, "the value of a digit is the product of its faces value and its places value". Artinya nilai digit adalah produk dari nilai nominal dan nilai tempatnya. Prinsip yang ketiga yaitu, "the value of a numeral is the sum of the values of the individual digit". Artinya Nilai bilangan adalah jumlah dari nilai-nilai digit tunggal.

D'Augustine dan Smith (1992, p.248) berpendapat karena anak-anak di kelas-kelas awal memiliki pengalaman terbatas dengan pecahan dan nilai tempat, maka guru dianjurkan untuk menggunakan model untuk membantu anak-anak memahami bahwa nilai tempat di sebelah kanan desimal merupakan perluasan dari nilai tempat.

T.P Carpenter, et al. (Bennet, Burton, \& Nelson, 2012, p.344) menyatakan, "it is important that decimals be thought of as a number and the ability to relate them to models should assist in this.

Resnick et al. (Bennet, Burton, \& Nelson (2012, p.344) mengatakan "as with fraction, an understanding of the simbolism for representing decimals is essential to developing understanding of operations with decimal".

Berdasarkan pendapat-pendapat tersebut dapat disimpulkan bahwa pembelajaran mengenai penjumlahan dan pengurangan bilangan desimal akan lebih efektif bila menggunakan media pembelajaran. Media manipulatif merupakan media pembelajaran yang tepat untuk membelajarkan peserta didik pada materi bilangan desimal.

Tabel 1. Three Levels of "Change" Types in Problem

\begin{tabular}{ccl}
\hline Change Types & Join & Separate \\
\hline \multirow{2}{*}{ Result number } & Standard & Standard \\
unknown & sentence: & sentence: \\
& $\mathrm{A}+\mathrm{B}=\square$ & $\mathrm{A}-\mathrm{B}=\square$ \\
Change number & Standard & Standard \\
unknown & sentence: & sentence: \\
& $\mathrm{A}+\square=\mathrm{B}$ & $\mathrm{A}-\square=\mathrm{B}$ \\
Initial number & Standard & Standard \\
unknown & sentence: & sentence: \\
& $\square+\mathrm{A}=\mathrm{B}$ & $\square-\mathrm{A}=\mathrm{B}$ \\
\hline
\end{tabular}

Sumber: Yen Hua Chen, Chiu-Pin Lin, Chee-Kit Looi, et al. (2012, p. 2)

Yen-Hua Chen, Chiu-Pin Lin, Chee-Kit Looi, et al., (2012, p.2), mengembangkan tingkat kesulitan dari tiga level menjadi lima level. Level 1 merupakan jawaban dari sebuah ekspresi aritmatika (bilangan hasil tidak diketahui), menanamkan keterampilan dasar penjumlahan dan pengurangan, misalnya: $3,23 \pm 2,34=\square$. Pada Level 2, operator aritmatika dihapus. Peserta didik diminta untuk memahami konsep operator aritmatika, misalnya: $3,23 \square 2,34=$ 5,57. Pada Level 3, bilangan penjumlah dihapus, misalnya: $3,23 \pm \square=5,57$. Pada Level 4, bilangan yang dijumlah dihapus, misalnya: $\square \pm$ $3,23=5,57$. Pada Level 5, merupakan tingkat kesulitan yang paling tinggi, bilangan penjumlah dan bilangan yang dijumlahkan tidak diketahui. Sebagai contoh: $\square \pm \square=5,57$.

Hedden (Durmus \& Karakirik, 2006, p.120) menyatakan "manipulative materials are concrete models that involve mathematical concepts, appealing to several senses including the socio-cultural needs that can be touched and moved around by the learners. Smaldino, Lowther, \& Russell (2007, p.6) menyatakan, "manipulatives are three dimensional and can be touch and handled by students". Howden (Bangurah, 2007, p.13) menyatakan, "mathematics manipulative materials as physical models used to express a mathematical idea. It can 
be any object that will illustrate the properties inherent to the idea it is used to represent".

Post \& Cramer (Wheeldon, 2008, p.48) menyatakan, "using manipulatives helps students to develop strong mental image". Penggunaan benda kongkret dapat meningkatkan prestasi matematika dinyatakan oleh Sowell (Bennet, Burton, \& Nelson, 2012, p.224), "mathemetics achievement is increased throught the longterm use of concrete instructional materials and students' attitudes toward mathematics are improved when they have instruction with concrete materials provided by teachers knowledgeable about their use".

Berdasarkan pernyataan-pernyataan tersebut dapat disimpulkan bahwa media manipulatif merupakan alat komunikasi dari guru kepada peserta didik berupa benda-benda yang dapat disentuh dan dipindah letaknya oleh peserta didik. Penggunaan benda-benda kongkret dalam pembelajaran pada waktu yang lama akan dapat meningkatkan prestasi dan sikap peserta didik terhadap matematika.

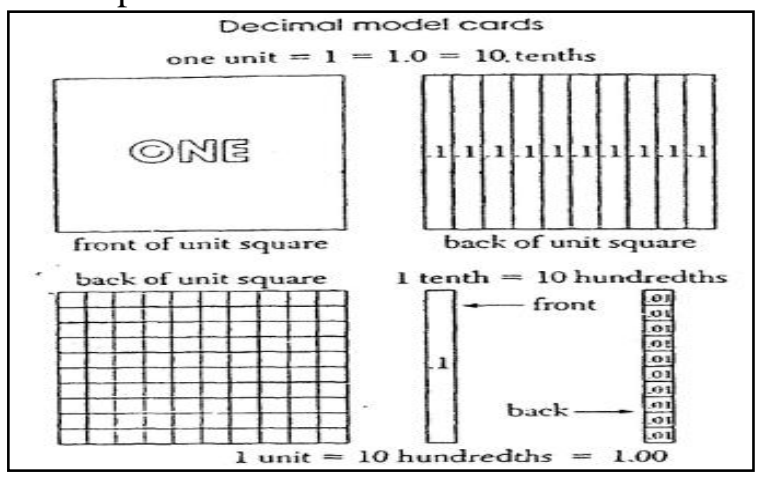

Gambar 1. Model Media Manipulatif Bilangan Desimal menurut D'Augustine \& Smith, 1992, p.251)

Media manipulatif pada gambar di atas merupakan kartu pecahan yang menunjukkan pecahan pecahan pesepuluhan dan pecahan perseratusan. Penggunaan kartu pecahan tersebut dalam pembelajaran akan membuat peserta didik memahami bahwa pada satu satuan terdapat sepuluh pecahan persepuluhan, dan pada satu pecahan persepuluhan terdapat sepuluh pecahan perseratusan.

Ross \& Olsen (Cook, 2009, p.28) menyatakan, "integrated thematic instruction is, the name given to a brain-compatible, fully integrated instructional model, developed by Susan Kovalik of Susan Kovalik \& Associates. The integrated model consisted of a central theme with yearly, monthly, weekly, and daily topics, key points, and political/social action".
Adeyemi (2010, p.11) menyatakan, "the interdiciplinary approach: as the name suggests, it is an approach of using two subjects in the teaching of topic, concept or theme". Adeyemi (2010, p.11) menyatakan

the multidiciplinary approach denote the teaching of concepts across more than two subjects or disciplines. The instruction may be organized on fundamental issues common to the three academic disciplines instead of teaching the students in a disjointed and unconnected manner.

Hubungan antara pendekatan multidisipliner dengan pendekatan integratif dinyatakan oleh Adeyemi (2010, p.11) dengan, "the use of the multidisciplinary approach in instruction can equally be referred to as the integrated approach. Integration in this sense means using relevan ideas from many other disciplines to, 'do justice' to the topic or problem at hand'.

Pembelajaran tematik integratif menurut Ahmadi (2014, pp.91-92) memiliki ciri dan karakteristik yang terdiri atas enam item. Ciri dan karakteristik tersebut antara lain: (1) berpusat pada peserta didik, (2) memberikan pengalaman langsung pada peserta didik, (3) pemisahan antar mata pelajaran tidak nampak, (4) menyajikan konsep dari berbagai mata pelajaran dalam suatu proses pembelajaran, (5) bersifat luwes (fleksibel), (6) hasil pembelajaran dapat berkembang sesuai dengan minat dan kebutuhan peserta didik.

Berdasarkan pendapat-pendapat tersebut dapat disimpulkan bahwa pembelajaran tematik integratif merupakan model pembelajaran yang terintegrasi penuh berpusat pada sebuah tema, berlangsung selama kurun waktu sehari, seminggu, sebulan, atau setahun dan merupakan ide-ide relevan dari berbagai disiplin ilmu lain yang sesuai dengan topik atau masalah yang dihadapi dengan kadar yang adil/sama.

Rumusan masalah dalam penelitian ini adalah: (1) apakah penampilan guru dalam mengajar menggunakan media manipulatif berada pada klasifikasi baik untuk dapat meningkatkan motivasi belajar dan keterampilan hitung peserta didik? (2) apakah penggunaan media manipulatif dalam pembelajaran dapat meningkatkan motivasi belajar peserta didik kelas IV B SDN 15 Ulu Gadut? (3) apakah penggunaan media manipulatif dalam pembelajaran dapat meningkatkan keterampilan hitung peserta didik kelas IV B SDN 15 Ulu Gadut? 
Berdasarkan rumusan permasalahan, maka tujuan penelitian ini adalah: (1) untuk mengetahui bahwa penampilan guru dalam mengajar menggunakan media manipulatif berada pada klasifikasi baik agar dapat meningkatkan motivasi belajar dan keterampilan hitung peserta didik. (2) untuk meningkatkan motivasi belajar melalui media manipulatif pada pembelajaran tematik integratif peserta didik kelas IV B SDN 15 Ulu Gadut Padang. (3) untuk meningkatkan keterampilan hitung pecahan desimal melalui media manipulatif pada pembelajaran tematik integratif peserta didik kelas IV B SDN 15 Ulu Gadut Padang.

\section{METODE}

\section{Jenis Penelitian}

Penelitian ini merupakan jenis penelitian tindakan kelas untuk melakukan perbaikan terhadap kegiatan pembelajaran. Penelitian tindakan dikembangkan sesuai desain PTK model Kemmis \& McTaggart (McTaggart, 1991, p.32). Melalui model penelitian tindakan membimbing partisipan dengan tahap di dalam masing-masing siklus: perencanaan, tindakan atau observasi, dan refleksi. Untuk lebih jelasnya dapat dilihat melalui Gambar 2.

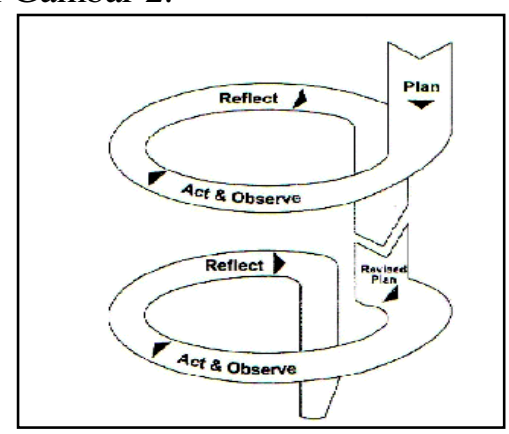

Gambar 2. Siklus PTK Model Kemmis \&

McTaggart (Sumber: McTaggart, 1991, p.32)

\section{Waktu dan Tempat Penelitian}

Penelitian dilakukan SDN 15 Ulu Gadut, Kecamatan Pauh, Kota Padang. SDN 15 Ulu Gadut pada semester II tahun pelajaran 2014/ 2015 di SDN 15 Ulu Gadut mulai tanggal 2 maret 2015 sampai tanggal 10 April 2015.

\section{Subjek Penelitian}

Subjek dalam penelitian ini adalah peserta didik kelas IV B SDN 15 Ulu Gadut dengan jumlah 37 orang peserta didik yang terdiri atas 20 peserta didik laki-laki dan 17 peserta didik perempuan. Karakteristik peserta didik kelas IV B ini berada pada kisaran umur 9 - 11 tahun yang berdasarkan teori Piaget berada dalam tahap operasional kongkret yang dalam memahami sesuatu sebagaimana kenyataannya, mampu mengkonservasi angka, serta memahami konsep melalui pengalaman sendiri dan lebih objektif.

\section{Skenario Tindakan}

Pelaksanaan tindakan siklus I dilakukan tiga kali pembelajaran yaitu pada pembelajaran 1, pembelajaran 3, dan pembelajaran 4. Penggunaan media manipulatif berupa papan pecahan persepuluhan dan perseratusan dan media kartu bergambar yang dibuat dari triplek mika sehingga pada bagian belakangnya dapat dituliskan bilangan decimal.

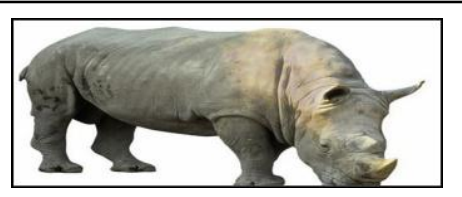

Badak Bercula Satu (latin : Rhinoceras Sundaicus) Adalah salah satu hewan langka khas Indonesia. Walau sekarang sudah tidak banyak, hanya sekitar 50 ekor saja dapat ditemukan di hutan ujung kulon. Merupakan hewan herbivora pemakan daun-daunan. Sumber : http://www.azamku.com/10hewan-langka-di-indonesia

Gambar 3. Media Manipulatif Kartu Bergambar

Media kartu bergambar tersebut dibuat dengan ukuran $10 \times 10 \mathrm{~cm}$. Pada pembelajaran 1 gambar pada kartu disesuaikan dengan indikator muatan IPA yaitu membedakan hewan langka dan tidak langka. Pada pembelajaran 3 disesuaikan dengan indikator muatan PPKn yaitu menjelaskan kewajiban sebagai warga sehubungan dengan pemanfaatan tumbuhan. Pada pembelajaran 4 disesuaikan dengan indikator muatan IPA yaitu mendeskripsikan hubungan antara kegiatan manusia dengan kelangkaan hewan.

Selain menggunakan media gambar peserta didik juga diminta untuk menentukan pecahan desimal dengan menggunakan tanda "<", "> , dan "=" serta melakukan penjumlahan dan pengurangan pada bilangan desimal dengan menggunakan media papan pecahan persepuluhan dan perseratusan sesuai gambar berikut.

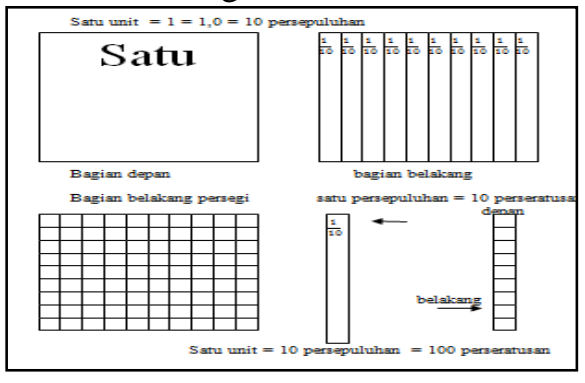

Gambar 4. Model Media Manipulatif 


\section{Teknik Pengumpulan Data}

Teknik yang digunakan pada pengumpulan data adalah triangulasi untuk memperoleh data tentang motivasi belajar peserta didik dengan menggunakan triangulasi teknik. Data yang dikumpulkan penelitian ini adalah data mengenai kegiatan guru dalam pembelajaran, motivasi, dan keterampilan hitung peserta didik dalam penjumlahan dan pengurangan bilangan desimal dengan menggunakan media manipulatif. Teknik pengumpulan data yang digunakan dalam penelitian ini adalah teknik tes dan non tes.

Alat pengumpul data yang digunakan dalam penelitian ini adalah lembar observasi checklist dan lembar instrumen tes.

\section{Teknik Analisis Data}

Analisis Hasil Observasi

\section{Observasi terhadap Kegiatan Guru}

Analisis hasil observasi terhadap kegiatan guru dalam pembelajaran dilakukan menggunakan lembar observasi yang diadaptasi dari Kemdikbud pada kurikulum 2013. Jumlah item yang diamati ada 43 butir dengan skala penilaian 1 sampai 5. Nilai 1 untuk buruk sekali, nilai 2 untuk buruk, nilai 3 untuk sedang, nilai 4 untuk baik, dan nilai 5 untuk baik sekali. Kriteria hasil pengukuran dilakukan dengan menggunakan klasifikasi yang ditentukan dengan rerata ideal $\left(\mathrm{X}_{\mathrm{i}}\right)$ dan simpangan baku ideal $\left(\mathrm{sb}_{\mathrm{i}}\right)$ menurut pendapat Widoyoko $(2014$, p.238) yang terlihat pada tabel 2 .

Tabel 2.Klasifikasi Skor Observasi Guru

\begin{tabular}{cc}
\hline Jumlah skor & Klasifikasi \\
\hline$X>180,60$ & Sangat Baik \\
$146,20<X \leq 180,60$ & Baik \\
$111,80<X \leq 146,20$ & Cukup \\
$77,40<X \leq 111,80$ & Kurang \\
$X \leq 77,40$ & Sangat Kurang \\
\hline \multicolumn{2}{c}{ Sumber: Widoyoko (2014, p.238) }
\end{tabular}

\section{Observasi terhadap Motivasi Peserta Didik}

Analisis hasil observasi terhadap motivasi peserta didik dalam kegiatan pembelajaran dilakukan dengan menggunakan lembar observasi motivasi yang terdiri 17 item dengan skal penilaian 1 sampai 5. Nilai 5 untuk selalu, nilai 4 untuk sering, nilai 3 untuk kadang-kadang, nilai 2 untuk jarang, dan nilai 1 untuk tidak pernah. Kriteria hasil pengukuran dilakukan dengan menggunakan klasifikasi yang ditentukan dengan rerata ideal $\left(\mathrm{X}_{\mathrm{i}}\right)$ dan simpangan baku $\left(\mathrm{sb}_{\mathrm{i}}\right)$ menurut pendapat Widoyoko (2014, p.238) yang terdapat pada Tabel 3.

Tabel 3. Klasifikasi Skor Observasi Motivasi Peserta Didik

\begin{tabular}{cc}
\hline Rerata skor & Klasifikasi \\
\hline$X>71,4$ & Sangat Baik \\
$57,8<X \leq 71,4$ & Baik \\
$44,2<X \leq 57,8$ & Cukup \\
$30,6<X \leq 44,2$ & Kurang \\
$X \leq 44,2$ & Sangat Kurang \\
\hline Sumber: Widoyoko (2014, p.238)
\end{tabular}

Analisis Hasil Tes Skala Motivasi Belajar Peserta Didik

Analisis hasil tes skala motivasi belajar peserta didik pada penelitian ini dilakukan dengan menggunakan lembar skala motivasi yang terdiri 23 item dengan skala penilaian 1 sampai 4. Nilai 4 untuk selalu, 3 untuk kadang-kadang, 2 untuk jarang, dan 1 untuk tidak pernah. Klasifikasi hasil tes skala motivasi peserta didik dibagi menjadi empat klasifikasi yaitu sangat tinggi, tinggi, rendah, dan sangat rendah karena disesuaikan dengan tes skala motivasi yang menggunakan skala penilaian 1 sampai 4. Kriteria hasil pengukuran menggunakan klasifikasi yang ditentukan dengan rerata ideal (X) dan simpangan baku $\left(\mathrm{sb}_{\mathrm{x}}\right)$ menurut pendapat Mardapi (2010, p.123) yang terlihat Tabel 4.

Tabel 4. Klasifikasi Hasil Tes Skala Motivasi Peserta Didik

\begin{tabular}{cc}
\hline Skor Peserta Didik & Klasifikasi \\
\hline$X \geq 69$ & Sangat tinggi \\
$69>X \geq 57,5$ & Tinggi \\
$57,5>X \geq 46$ & Rendah \\
$X<46$ & Sangat rendah \\
\hline \multicolumn{2}{c}{ Sumber: Mardapi (2010, p.123) }
\end{tabular}

Analisis Hasil Tes

Tes keterampilan hitung peserta didik merupakan soal isian dengan penilaian 1 dan 0 . Skor hasil tes keterampilan hitung peserta didik diperoleh dengan menghitung jumlah jawaban yang betul dibagi jumlah soal x 100 . Untuk memperoleh skor keseluruhan dari level 1 sampai 5 dengan menggunakan skor rata-rata hasil tes dari level 1 sampai 5.

Kriteria keberhasilan dalam penelitian ini meliputi: (1) guru telah melakukan pembelajaran dengan klasifikasi baik pada seluruh item yang diamati untuk mendukung peningkatan motivasi belajar peserta didik, (2) terjadinya peningkatan motivasi peserta didik setelah kegiatan pembelajaran minimal $85 \%$ skor skala motivasi belajar 
peserta didik berada pada klasifikasi tinggi, (3) skor hasil pengamatan terhadap motivasi belajar peserta didik minimal $85 \%$ berada pada klasifikasi baik, (4) terjadi peningkatan skor keterampilan hitung dalam dua kriteria, yaitu: (a) jika skor hasil tes peserta didik secara klasikal $85 \%$ lebih tinggi atau sama dengan KKM pada setiap level, (b) Jika $85 \%$ skor peserta didik dihitung secara keseluruhan dalam lima level lebih tinggi atau sama dengan KKM, (5) KKM yang digunakan adalah KKM kelas IV yaitu 7,5.

\section{HASIL DAN PEMBAHASAN}

\section{Hasil Penelitian}

Pembelajaran Tematik-Integratif

Tabel 5 menunjukkan rata-rata skor hasil pengamatan terhadap guru pada siklus 1 terdapat 4 item yang memperoleh skor dengan klasifikasi cukup. skor dengan klasifikasi sangat baik sebanyak 37 item dan sebanyak sebanyak 2 item memperoleh skor 4,33 dengan klasifikasi sangat baik. Rata-rata skor hasil pengamatan terhadap guru pada siklus 2 terdapat 7 item yang memperoleh skor dengan klasifikasi sangat baik dan sebanyak 36 item memperoleh skor dengan klasifikasi baik. Rata-rata jumlah skor pada siklus 2 senilai 175,83 . Peningkatan jumlah skor ratarata dari siklus 1 ke siklus 2 sebesar 15,50.

Tabel 5. Data Hasil Observasi terhadap

Penampilan Guru dalam Pembelajaran

\begin{tabular}{lllll}
\hline \multirow{2}{*}{ Klasifikasi } & Skor & \multicolumn{3}{c}{$\begin{array}{c}\text { Jumlah Item } \\
\text { pada Siklus }\end{array}$} \\
\cline { 2 - 5 } & & $\mathbf{1}$ & $\mathbf{2}$ & $\mathbf{3}$ \\
\hline Cukup & 3 & 3 & - & - \\
$($ Skor $3,4>\mathrm{X}>2,6)$ & 3,25 & 1 & - & - \\
\hline & 3,5 & 13 & 1 & - \\
& 3,67 & 2 & - & - \\
Baik & 3,83 & - & 2 & - \\
(Skor 4,2 > X > 3,4 ) & 3,85 & 11 & - & - \\
& 4 & 8 & 25 & 20 \\
& 4,17 & 2 & 8 & - \\
\hline Sangat Baik & 4,2 & - & - & 2 \\
\hline Skor X $>$ 4,2) & 4,33 & 3 & 1 & 2 \\
\multicolumn{1}{c}{ Jumlah } & 4,5 & - & 6 & 19 \\
\hline
\end{tabular}

Rata-rata skor hasil pengamatan terhadap guru pada siklus 3 terdapat 21 item yang memperoleh skor dengan klasifikasi sangat baik dan sebanyak 22 item memperoleh skor dengan klasifikasi baik. Rata-rata jumlah skor pada siklus 3 senilai 182,5 . Peningkatan jumlah skor rata-rata dari siklus 2 ke siklus 3 senilai 6,67 poin.

\section{Motivasi Belajar \\ Pengamatan terhadap Peserta Didik dalam Pembelajaran}

Pengamatan terhadap peserta didik dilakukan oleh guru praktikan dan dua orang kolaborator. Peneliti dan rekan sejawat juga meminta informasi dari guru kelas untuk mengetahui sikap peserta didik yang diamati sehari-hari sebelum kegiatan penelitian dilakukan. Hasil pengamatan terhadap motivasi peserta didik dapat dilihat pada Tabel 6 .

Tabel 6. Rekap Hasil pengamatan terhadap Peserta Didik

\begin{tabular}{lllll}
\hline & \multicolumn{3}{l}{ Pembelajaran } & \multirow{2}{*}{ Rata-Rata } \\
\cline { 2 - 4 } & $\mathbf{1}$ & $\mathbf{2}$ & $\mathbf{3}$ & \\
\hline Siklus 1 & 60,78 & 62,05 & 63,30 & 62,04 \\
Siklus 2 & 63,86 & 65,81 & 67,00 & 65,56 \\
Siklus 3 & 67,59 & 68,10 & 68,80 & 68,16 \\
\hline
\end{tabular}

Data pada Tabel 6 menunjukkan bahwa rata-rata hasil pengamatan terhadap peserta didik pada siklus 1 berada pada skor dengan klasifikasi baik. klasifikasi baik dan mengalami peningkatan dari pembelajaran 1 ke pembelajaran 2 sebesar 1,27 poin. Peningkatan skor dari pembelajaran 2 ke pembelajaran 3 sebesar 1, 25 poin. Rata-rata hasil pengamatan terhadap peserta didik pada siklus 2 berada pada skor dengan klasifikasi baik. Peningkatan skor dari pembelajaran 1 ke pembelajaran 2 sebesar 1,95 poin, dan peningkatan skor dari pembelajaran 2 ke pembelajaran 3 sebesar 1,19 poin. Rata-rata hasil pengamatan terhadap peserta didik pada pembelajaran 1 siklus 3 berada pada skor dengan klasifikasi baikPeningkatan skor dari pembelajaran 3 siklus 2 ke pembelajaran 1 siklus 2 sebesar 0,59 poin. Peningkatan skor dari pembelajaran 1 ke pembelajaran 2 sebesar 0,51 poin, dan peningkatan skor dari pembelajaran 2 ke pembelajaran 3 sebesar 0,7 poin.

\section{Hasil Tes Skala Motivasi Belajar Peserta Didik}

Data pada Tabel 7 menunjukkan bahwa pada siklus 1 hampir skor dengan klasifikasi sangat tinggi, hanya satu peserta didik yang memperoleh skor 64 dengan klasifikasi tinggi. Peserta didik memperoleh skor tertinggi senilai 91 dan skor terendah senilai 64. Skor 78 dan 80 merupakan skor yang paling banyak diperoleh oleh peserta didik dengan jumlah peserta didik yang memperolehnya sebanyak 4 peserta didik. Jumlah skor rata-rata kelas tes skala motivasi peserta didik berada pada skor 79,41 yang berada pada klasifikasi sangat tinggi. 
Data pada Tabel 7 menunjukkan bahwa jumlah skor rata-rata kelas tes skala motivasi peserta didik pada siklus 2 berada pada skor total 85,05 dengan klasifikasi sangat tinggi. Semua peserta didik memperoleh skor dengan kategori sangat tinggi. Peningkatan hasil tes skala motivasi peserta didik pada siklus $1 \mathrm{ke}$ siklus 2 senilai 6,65 poin.

Data Tabel 7 menunjukkan bahwa jumlah skor rata-rata kelas tes skala motivasi peserta didik pada siklus 3 berada pada skor total 87,05 dengan klasifikasi sangat tinggi. Pada siklus 3 ini semua peserta didik memperoleh skor dengan klasifikasi sangat tinggi. Skor yang diperoleh peserta didik berkisar antara 79 sampai 92. Peningkatan hasil tes skala motivasi peserta didik pada siklus 2 ke siklus 3 senilai 2 poin.

Tabel 7. Rekap Hasil Tes motivasi Peserta didik

\begin{tabular}{|c|c|c|c|c|}
\hline \multirow[t]{2}{*}{ Klasifikasi } & \multirow[t]{2}{*}{ Skor } & \multicolumn{3}{|c|}{$\begin{array}{c}\text { Jumlah Peserta Didik } \\
\text { yang Memperoleh Skor } \\
\text { pada Siklus }\end{array}$} \\
\hline & & 1 & 2 & 3 \\
\hline $\begin{array}{l}\text { Rendah (Skor } \\
57,5>X \geq 46 \text { ) } \\
\end{array}$ & - & - & - & - \\
\hline $\begin{array}{l}\text { Tinggi (Skor } 69 \\
>X \geq 57,5)\end{array}$ & 64 & 1 & - & - \\
\hline \multirow{21}{*}{$\begin{array}{l}\text { Sangat Tinggi } \\
(\text { Skor } X \geq 69 \text { ) }\end{array}$} & 71 & 2 & - & - \\
\hline & 73 & 3 & - & - \\
\hline & 74 & 1 & - & - \\
\hline & 75 & 3 & - & - \\
\hline & 76 & 2 & - & - \\
\hline & 77 & 4 & - & - \\
\hline & 78 & 1 & 1 & - \\
\hline & 79 & 3 & 1 & 2 \\
\hline & 80 & 4 & 2 & - \\
\hline & 81 & - & 4 & 2 \\
\hline & 82 & 3 & 3 & 2 \\
\hline & 83 & 1 & 3 & 1 \\
\hline & 84 & 2 & 4 & 1 \\
\hline & 85 & - & 2 & 3 \\
\hline & 86 & 1 & 3 & 6 \\
\hline & 87 & 1 & 1 & 1 \\
\hline & 88 & - & 5 & 4 \\
\hline & 89 & 2 & 3 & 3 \\
\hline & 90 & 2 & 2 & 4 \\
\hline & 91 & 1 & 3 & 3 \\
\hline & 92 & - & - & 5 \\
\hline Jumlah & & 37 & 37 & 37 \\
\hline
\end{tabular}

\section{Hasil Tes Keterampilan Hitung}

Tes Pratindakan

Data yang terdapat pada Tabel 8 menyatakan bahwa rata-rata hasil tes keterampilan hitung penjumlahan dan pengurangan pecahan desimal peserta didik pada level 1 adalah 49,19, level 2 adalah 54,59, level 3 adalah 35,68, level
4 adalah 26,49, dan level 5 adalah 43,78.pada tes pratindakan masih jauh dari Kriteria Ketuntasan (KKM) yang ditetapkan yaitu 75. Skor tertinggi yang dicapai peserta didik pada setiap level adalah 60 dan nilai teren-dah pada level I, II, dan V adalah 20, sedangkan skor terendah untuk level III dan IV adalah 0 (nol). Hal ini terjadi karena peserta didik belum memahami konsep bilangan desimal.

Tabel 8. Rekap Hasil Tes Keterampilan Hitung dari Tes Pra Tindakan sampai Siklus 3

\begin{tabular}{|c|c|c|c|c|c|c|}
\hline \multirow{2}{*}{ Tes } & \multicolumn{5}{|c|}{ Skor pada level } & \multirow{2}{*}{$\begin{array}{l}\text { Rata- } \\
\text { rata }\end{array}$} \\
\hline & I & II & III & IV & $\mathbf{V}$ & \\
\hline Pratindakan & 49,19 & 54,59 & 35,68 & 26,49 & 43,78 & 41,95 \\
\hline Siklus 1 & 76,22 & 81,08 & 55,68 & 42,70 & 58,92 & 62,92 \\
\hline Siklus 2 & 87,03 & 86,49 & 68,65 & 64,86 & 67,57 & 74,92 \\
\hline Siklus 3 & 90,81 & 93,51 & 75,14 & 75,68 & 76,76 & 82,38 \\
\hline
\end{tabular}

Siklus 1

Data pada Tabel 8 menyatakan bahwa rata-rata kelas hasil tes keterampilan hitung peserta penjumlahan dan pengurangan pecahan desimal peserta didik pada siklus 1 level 1 dan level 2 telah berada di atas KKM yang ditetapkan yaitu 75, sedangkan level 3, 4 dan 5 masih berada di bawah KKM atau belum tuntas.

\section{Siklus 2}

Data pada Tabel 8 menyatakan bahwa rata-rata kelas hasil tes keterampilan hitung peserta didik pada level I adalah 87,03, level II dengan rata-rata 86,49 , level III adalah 68,65 , level IV adalah 64,86, dan level V adalah 67,57 dengan skor rata-rata 74,92. Data tersebut menunjukkan bahwa rata-rata hasil tes keterampilan hitung penjumlahan dan pengurangan pecahan desimal peserta didik pada siklus 2, level I dan level II telah berada di atas KKM yang ditetapkan yaitu 75, sedangkan level 3, 4 dan 5 masih berada di bawah KKM atau belum tuntas.

\section{Siklus 3}

Data pada Tabel 8 menunjukkan bahwa rata-rata kelas hasil tes keterampilan hitung peserta didik pada level I adalah 90,81, level II dengan rata-rata 93,51 , level III adalah 75,14 , level IV adalah 75,68, dan level V adalah 76,76 dengan skor rata-rata 82,38. Data tersebut menunjukkan bahwa rata-rata kelas hasil tes keterampilan hitung penjumlahan dan pengurangan pecahan desimal peserta didik pada siklus telah berada di atas KKM yang ditetapkan yaitu 75 . 


\section{Pembahasan}

\section{Pembelajaran Tematik Integratif}

Berdasarkan Tabel 5 dapat dilihat bahwa jumlah item yang memperoleh skor dengan klasifikasi cukup pada siklus 1 mengalami peningkatan sehingga skor dengan klasifikasi cukup tidak terdapat lagi pada siklus 2. Pada siklus 3 penampilan guru mendapat skor dengan klasifikasi baik dan sangat baik dan tidak terdapat skor dengan klasifikasi cukup.

Klasifikasi cukup ini memang perlu ditingkatkan, karena menurut Djohar $(2006,10)$, "selain memiliki kompetensi mengajar dalam bidang masing-masing guru juga dituntut untuk memiliki profesi untuk menjalankan tugas sebagai guru dengan baik dan terampil dalam melaksanakan tugas kesehariannya". Pendapat ini mengisyaratkan bahwa guru harus dapat melaksanakan tugas-tugas kesehariannya sebagai guru dengan baik dan terampil, karena peran guru dalam pembelajaran adalah sebagai fasilitator, mediator, dan pembimbing yang membantu proses perubahan pengetahuan agar peserta didik dapat mencapai pengetahuan yang lebih sempurna dibandingkan pengetahuan sebelumnya (Daryanto, 2013, p.3).

Item yang memperoleh skor dengan klasifikasi cukup pada siklus 1 diantaranya adalah: (1) memfasilitasi kegiatan yang memuat komponen eksplorasi, elaborasi, dan konfirmasi yang merupakan item ke-12. Kegiatan ini belum maksimal dilakukan guru karena waktu untuk mengadakan kegiatan tersebut terpakai oleh kegiatan peserta didik dalam menyelesaikan lembar kerja. (2) melaksanakan pembelajaran sesuai dengan alokasi waktu yang direncanakan yang merupakan item ke-17. Hal tersebut terjadi karena waktu yang dirancang oleh guru dan kolaborator dalam RPP tidak sesuai dengan pelaksanaan pembelajaran. (3) menggunakan bahasa lisan secara jelas dan lancar yang merupakan item ke-38. Pada item ini sebenarnya guru telah menggunakan bahasa lisan yang baik dan lancar, namun observer hanya memberikan skor dengan kategori cukup karena pada saat pembelajaran masih banyak pertanyaan dari peserta didik mengenai penggunaan media papan desimal padahal guru sudah menjelaskan pada saat sebelum kegiatan. (4) melakukan refleksi atau membuat rangkuman dengan peserta didik yang merupakan item ke-40. Kegiatan memberikan rangkuman pada peserta didik memang masih sedikit dilakukan oleh guru karena keterbatasan waktu.
Item yang mengalami peningkatan adalah item ke-38 yaitu menggunakan bahasa lisan secara jelas dan lancar. Guru memang harus meningkatkan item ini karena bahasa yang jelas dan lancar akan membuat peserta didik memahami apa yang diinginkan guru, sehingga peserta didik dapat memperoleh pengetahuan secara optimal. Item kedua yang mengalami peningkatan adalah item ke-40 melakukan refleksi atau membuat rangkuman dengan melibatkan peserta didik. Item ini merupakan item yang penting karena melalui kegiatan ini peserta didik dapat memahami apa yang telah dipelajari dalam pembelajaran.

Keempat item yang memperoleh skor dengan kategori cukup pada siklus 1 telah mengalami peningkatan dan mendapat skor dengan klasifikasi baik, artinya guru telah berupaya melakukan perbaikan pembelajaran karena sesuai dengan pernyataan Degeng (2013, p.36) pada halaman 64 yaitu, "Agar proses belajar menjadi lebih efektif dan efisien, maka usaha yang dilakukan untuk meningkatkan kualitas pembelajaran adalah dengan ilmu merancang (desain) pembelajaran (Instructional Science)". Karena Ilmu Pembelajaran menaruh perhatian pada upaya untuk meningkatkan pemahaman dan memperbaiki proses pembelajaran.

Pada tabel terlihat bahwa item yang mendapat skor sangat baik pada rata-rata perolehan skor hasil observasi pembelajaran tematik integratif pada siklus 3 sebanyak 19 item. Beberapa item yang memperoleh skor sangat baik itu diantaranya yaitu: (1) melibatkan peserta didik dalam media pembelajaran yang merupakan item ke-32, (2) menumbuhkan partisipasi aktif peserta didik melalui interaksi guru, peserta didik, sumber belajar yang merupakan item ke33, (3) merespon positif partisipasi peserta didik yang merupakan item ke-34,4) menumbuhkan keceriaan atau antusiasme peserta didik dalam belajar yang merupakan item ke-37, dan 5) melakukan refleksi atau membuat rangkuman dengan melibatkan peserta didik.

Berdasarkan pada ciri dan karakteristik pembelajaran tematik integratif menurut Ahmadi (2014, pp.91-92) yang terdiri atas enam item diantaranya: (1) berpusat pada peserta didik, (2) memberikan pengalaman langsung kepada peserta didik, (3) pemisahan antar mata pelajaran tidak nampak, (4) menyajikan konsep dari berbagai mata pelajaran dalam suatu proses pembelajaran, (5) bersifat luwes (fleksibel), (6) hasil pembelajaran dapat berkembang sesuai dengan minat dan kebutuhan peserta didik, maka 


\section{Jurnal Riset Pendidikan Matematika, 3 (1), Mei 2016 - 131}

Yuni Ristanti

dapat disimpulkan bahwa penampilan guru dalam pembelajaran yang mendapat skor sangat tinggi sesuai dengan ciri dan karakteristik pembelajaran tematik integratif. Pada item tiga pembelajaran yang dilakukan oleh guru masih belum bisa dilakukan, karena sulit bagi guru untuk melakukan pemisahan antar mata pelajaran tidak nampak ketika harus mempelajari tentang penjumlahan dan pengurangan pada pecahan desimal. Hal ini merupakan salah satu dari keterbatasan guru dalam penelitian ini.

Motivasi Belajar

\section{Pengamatan terhadap Peserta Didik dalam Pembelajaran}

Berdasarkan data pada Tabel 6 diketahui bahwa rata-rata hasil pengamatan terhadap peserta didik mengalami peningkatan dari siklus 1 sampai pada siklus 3. Peningkatan yang terjadi pada skor pengamatan terhadap peserta didik menunjukkan bahwa penggunaan media manipulatif dalam pembelajaran meningkatkan motivasi peserta didik dalam belajar sesuai dengan pendapat-pendapat ahli diantaranya pendapat: (a) Woolkfolk (2007, p.409) yang menyatakan bahwa motivasi peserta didik untuk belajar ada pada ciri dan keadaan yang melibatkan mengerjakan kegiatan akademik dengan serius, mencoba untuk mendapatkan hasil yang maksimal dalam kegiatan tersebut. Peserta didik termotivasi dalam belajar karena dilibatkan secara langsung pada pembelajaran dengan menggunakan media manipulatif papan pecahan desimal dan kartu bergambar, (b) Hicks \& Klimoski (Ayres, 2005 , p.26) menyatakan motivasi belajar sangat penting karena dapat membuat peserta didik untuk belajar dan mempertinggi perhatian mereka sehingga dapat menerima ide-ide baru. Motivasi belajar merupakan keinginan khusus peserta program belajar untuk dapat memahami dan menyelesaikan program yang dipelajari dengan baik. Penggunaan media papan pecahan desimal dan kartu bergambar membuat motivasi peserta didik meningkat karena peserta didik tertarik dengan media yang digunakan dan mempertinggi perhatian mereka pada pembelajaran, (c) Humaida (2012, p.49) yang menyatakan motivasi peserta didik secara alami ada hubungannya dengan keinginan peserta didik untuk berpartisipasi dalam proses pembelajaran. Tetapi juga menyangkut alasan atau tujuan yang mendasari mereka untuk terlibat atau tidak terlibat dalam kegiatan akademik. Meskipun peserta didik dapat termotivasi sama untuk melakukan tugas, sumber motivasi mereka mungkin berbeda. Pembelajaran dengan menggunakan media papan pecahan desimal dan kartu bergambar membuat motivasi peserta didik meningkat karena adanya keinginan peserta didik untuk berpartisipasi dan terlibat dalam proses pembelajaran.

\section{Tes Skala Motivasi Belajar Peserta Didik}

Berdasarkan data yang diperoleh pada siklus 1,2 , dan 3 dapat diketahui bahwa ratarata skor hasil tes skala motivasi peserta didik berada pada skor dengan klasifikasi sangat tinggi sejak siklus 1. Peneliti merasakan adanya indikasi bahwa peserta didik sebenarnya tahu apa yang sebaiknya dilakukan dalam belajar dan mengisi lembar tes skala karena ingin menjadi "anak baik", meskipun sebelum tes diberikan selalu diberi pengarahan bahwa hasil tes tidak berpengaruh pada nilai dan tidak perlu diberi nama. Kenyataannya, peserta didik tetap menuliskan nama pada lembar tes. Guru memanfaatkan hal ini untuk memotivasi peserta didik dalam pembelajaran ketika terlihat ada peserta didik yang mengalami penurunan motivasi. Hal ini sesuai dengan pendapat beberapa ahli diantaranya: (a) untuk membangkitkan motivasi peserta didik dalam belajar, Woolkfolk \& Nicolich (1984, p.289) menyatakan peserta didik diminta untuk menetapkan suatu tujuan yang layak, membuat rencana untuk menjangkau tujuan itu, dan memikirkan jalan untuk mengevaluasi kemajuan mereka, dan memikul tanggung jawab mereka secara pribadi. Guru dalam pembelajaran menanyakan pada peserta didik tujuan peserta didik belajar/sekolah, apa yang harus dilakukan dan bagaimana malakukan. Pertanyaan ini diberikan guru ketika peserta didik mulai kelihatan lengah dalam belajar untuk kembali membangkitkan semangat dan motivasi peserta didik, (b) Atkinson (Sud \& Kumar, 2006, p.42) menyatakan bahwa semua peserta didik dipengaruhi oleh motivasi berprestasi. Guru membangkitkan motivasi peserta didik untuk meningkatkan prestasi dengan memberikan kesempatan pada peserta didik bersaing menjadi yang terbaik, (c) Santrock (2011, p.438) menyatakan, bahwa jika peserta didik tidak menyelesaikan suatu tugas karena mereka bosan, hal ini menunjukkan ketiadaan motivasi. Jika peserta didik menghadapi tantangan, tetapi tetap berusaha mengalahkan rintangan, dalam hal ini motivasi dilibatkan. Penerapan dalam pembelajaran dilakukan guru dengan membangkitkan motivasi 
peserta didik agar tertantang dalam menyelesaikan suatu soal.

Teknik pengumpulan data tentang motivasi belajar peserta didik dalam penelitian ini menggunakan triangulasi teknik yaitu menggunakan teknik yang berbeda-beda pada sumber yang sama. Sumber yang digunakan adalah peserta didik kelas IV B. Teknik yang digunakan adalah teknik pengamatan terhadap motivasi peserta didik dalam pembelajaran dan tes skala motivasi.

Teknik triangulasi yang dilakukan sesuai dengan pendapat Susan Stainback (Sugiyono, 2013, p.330) yang menyatakan bahwa tujuan triangulasi bukan untuk mencari kebenaran tentang beberapa fenomena, tetapi lebih pada peningkatan pemahaman peneliti terhadap apa yang ditemukan. Pada penelitian ini pemahaman peneliti tentang peningkatan motivasi belajar peserta didik menggunakan media manipulatif lebih yakin dengan data yang didapat dari hasil pengamatan terhadap peserta didik.

Pada dasarnya hasil pengamatan dan tes skala motivasi sama-sama meningkatkan motivasi belajar peserta didik. Perbedaannya berada pada klasifikasinya, karena pada hasil tes skala motivasi hasilnya lebih tinggi dibandingkan dengan hasil pengamatan oleh observer. Namun, pemberian tes skala pada peserta didik tersebut juga penting karena guru dapat memanfaatkan hasil jawaban peserta didik untuk kembali membangkitkan motivasi peserta didik yang terlihat melemah.

Mathinson (Sugiyono, 2013, p.332) menyatakan bahwa nilai dari teknik pengumpulan data dengan triangulasi adalah untuk mengetahui data yang diperoleh convergent (meluas), tidak konsisten atau kontradiksi. Pada penelitian ini data yang diperoleh dari hasil pengamatan dan hasil tes skala motivasi dapat dikatakan sesuai atau tidak mengalami kontradiksi.

Tes Keterampilan Hitung

\section{Siklus 1}

Berdasarkan data yang terdapat pada Tabel 8, diketahui bahwa rata-rata kelas hasil tes keterampilan hitung peserta penjumlahan dan pengurangan pecahan desimal peserta didik pada siklus 1 level 1 dan level 2 telah berada di atas KKM yang ditetapkan yaitu 75 , sedangkan level 3, 4 dan 5 masih berada di bawah KKM atau belum tuntas. Hasil tes keterampilan hitung penjumlahan dan pengurangan pecahan desimal peserta didik pada level I yang mencapai KKM sebanyak 27 peserta didik sedangkan 10 orang peserta didik level 1 masih mendapat skor di bawah KKM. Peserta didik pada siklus 1 level II yang mencapai KKM sebanyak 30 peserta didik dan sisanya 7 orang peserta didik masih mendapat skor dibawah KKM. Hasil tes peserta didik pada level III yang mencapai KKM hanya 8 peserta didik dan peserta didik yang memperoleh skor dibawah KKM sebanyak 29 peserta didik. Hasil tes peserta didik pada level IV yang mencapai KKM hanya 1 peserta didik dan peserta didik yang memperoleh skor dibawah KKM sebanyak 36 orang. Hasil tes peserta didik pada level $\mathrm{V}$ yang mencapai KKM hanya 5 peserta didik dan peserta didik yang memperoleh skor dibawah KKM.

Kesalahan yang banyak dilakukan oleh peserta didik pada level 1 adalah kesalahan dalam menjumlahkan atau mengurangi bilangan. Ada beberapa peserta didik yang menggunakan operasi penjumlahan saja tanpa melihat bahwa operasi yang diminta adalah operasi pengurangan. Kesalahan pada level 2 terjadi karena peserta didik tidak teliti menghitung dan tidak menemukan jawaban akhirnya peserta didik cenderung mengisi dengan asal-asalan. Pada level 3 dan 4 kesalahan yang dilakukan peserta didik pada umumnya karena belum memahami hubungan antara penjumlahan dan pengurangan sehingga soal yang seharusnya dikurangi diselesaikan dengan menjumlah atau sebaliknya. Terkadang terlihat pada soal yang merupakan operasi pengurangan ada satu angka yang kelihatan dikurangi, tetapi angka yang lain dijumlah. Hal ini terjadi karena peserta didik tidak melakukan operasi penjumlahan dengan menyusun ke bawah.

Pada level V kesalahan dilakukan oleh peserta didik ketika melakukan operasi pengurangan. Pada peserta didik yang teliti ketika mengerjakan soal pada level sebelumnya, kesalahan terjadi karena kehabisan waktu dan sudah terpengaruh oleh peserta didik lain yang telah selesai mengerjakan. Kesalahan lain yang dilakukan oleh peserta didik adalah ketika operasi penjumlahan dan pengurangan menggunakan bilangan desimal yang berbeda nilai tempatnya. Atau bilangan desimal yang menggunakan angka nol.

\section{Siklus 2}

Berdasarkan pada Tabel 8, diperoleh data rata-rata kelas hasil tes keterampilan hitung peserta didik pada level I adalah 87,03, level II dengan rata-rata 86,49, level III adalah 68,65, 
level IV adalah 64,86, dan level V adalah 67,57 dengan skor rata-rata 74,92. Data tersebut menunjukkan bahwa rata-rata hasil tes keterampilan hitung penjumlahan dan pengurangan pecahan desimal peserta didik pada siklus 2, level I dan level II telah berada di atas KKM yang ditetapkan yaitu 75, sedangkan level 3, 4 dan 5 masih berada di bawah KKM atau belum tuntas.

Kesalahan yang dilakukan pada siklus 2 hampir sama dengan kesalahan yang dilakukan oleh peserta didik pada siklus 1 , namun pada siklus 2 peserta didik yang melakukan kesalahan lebih sedikit dibandingkan pada siklus 1 . Data peningkatan perolehan skor rata-rata peserta didik pada siklus 1 dan siklus 2 diperoleh berdasarkan Tabel 32 halaman 158 menunjukkan bahwa pada level I terjadi peningkatan sebesar 9,73 poin, level II sebesar 7,57 poin, level III sebesar 12,43 poin, level IV sebesar 22,16 poin, dan level V sebesar 8,65 poin.

\section{Siklus 3}

Data rekap analisis hasil tes keterampilan hitung peserta didik pada Tabel 8 menunjukkan bahwa rata-rata kelas hasil tes keterampilan hitung peserta didik pada level I adalah 90,81, level II dengan rata-rata 93,51, level III adalah 75,14 , level IV adalah 75,68, dan level V adalah 76,76 dengan skor rata-rata 82,38 . Data tersebut menunjukkan bahwa rata-rata kelas hasil tes keterampilan hitung penjumlahan dan pengurangan pecahan desimal peserta didik pada siklus telah berada di atas KKM yang ditetapkan yaitu 75 .

Persentase peserta didik yang telah mencapai KKM pada skor total hasil tes keterampilan hitung senilai $91,89 \%$ atau sebanyak 34 peserta didik. Meskipun beberapa peserta didik belum mencapai KKM pada level 3 dan 4 ataupun pada jumlah total tes, namun peningkatan yang diperoleh telah mencapai target dari penelitian ini. Target dari penelitian ini adalah rata-rata kelas hasil tes keterampilan hitung peserta didik telah mencapai KKM dan hasil tes keterampilan hitung peserta didik pada setiap level juga telah mencapai KKM.

Kesalahan yang dilakukan oleh peserta didik pada siklus 3 adalah kesalahan karena kurang teliti dalam menghitung. Peserta didik yang belum mencapai KKM akan diberikan remedial oleh guru kelas dalam pembelajaran selanjutnya. Peningkatan skor tes keterampilan hitung peserta didik dari siklus 2 ke siklus 3 yaitu pada level I terjadi peningkatan sebesar
3,78 poin, level II sebesar 7,02 poin, level III sebesar 6,49 poin, level IV sebesar 10,82 poin, dan level V sebesar 9,19 poin.

Peningkatan hasil keterampilan hitung peserta didik penjumlahan dan pengurangan pada pecahan desimal terjadi karena penggunaan media manipulatif papan pecahan desimal yang membuat peserta didik memahami nilai tempat pada pecahan desimal. Hal ini sesuai dengan pendapat ahli diantaranya: (a) Pendapat Witzel, Ferguson, \& Mink (2012, p.90) tentang tiga strategi yang perlu dilakukan oleh guru dalam membantu peserta didik yang masih belia untuk berjuang mengembangkan "number sense" dalam matematika diantaranya dengan penggunaan benda kongkret, mengajarkan keterampilan agar peserta didik lebih mahir, penggabungan pengalaman berbahasa, (b) D'Augustine \& Smith (1992, p.255) menyarankan penggunaan model manipulatif yang terdiri atas bilangan satuan, persepuluhan, dan perseratusan untuk menggambarkan penjumlahan pada bilangan decimal yang membantu peserta didik untuk memahami konsep bilangan pecahan desimal yang bersifat abstrak.

Pemberian tindakan yang dilakukan guru untuk memancing peserta didik dalam memahami hubungan antara operasi penjumlahan dan pengurangan pada bilangan desimal dilakukan pada waktu peserta didik baru masuk ke dalam kelas, sebelum istirahat dan sebelum pulang sekolah. Tindakan ini sesuai dengan teori yang dikemukakan oleh Thorndike tentang hukum kesiapan (Wangid, Mustadi, Erviana, \& Arifin, 2014, p.177) yang menyatakan bahwa kesiapan akan dapat dicapai apabila ada harapan, dan usaha dalam bentuk yang berulang-ulang hingga mencapai tujuan yang diinginkan yaitu berupa kesuksesan. Hukum kesiapan Thorndike tersebut, muncul dalam beberapa kondisi, diantaranya: (a) jika individu siap dan mau untuk bertindak, tapi tidak mau melakukan akan merasa puas, (b) jika individu siap untuk bertindak, tapi tidak mau melakukan, akan timbul ketidak puasan, (3) jika belum ada kecenderungan untuk bertindak namun dipaksa melakukan, akan menjengkelkan, dan (4) jika individu didukung oleh kesiapan kuat untuk memperoleh stimulus maka tindakan akan menimbulkan kepuasan individu sehingga asosiasi cenderung diperkuat.

Tindakan yang dilakukan guru sesuai dengan teori tersebut karena pada awal pelajaran peserta didik siap untuk menerima pelajaran. Pada waktu akan istirahat dan pulang sekolah, keinginan peserta didik untuk istirahat dan 
pulang membuat peserta didik siap untuk menerima pembelajaran yang diberikan oleh guru tentang hubungan antara operasi penjumlahan dan pengurangan pada bilangan desimal. Sehingga hasil tes keterampilan hitung peserta didik secara klasikal pada level III dan IV mengalami peningkatan serta mencapai KKM yang ditetapkan.

\section{SIMPULAN DAN SARAN}

\section{Simpulan}

Hasil Pengamatan terhadap Pembelajaran Guru

Hasil pengamatan terhadap penampilan guru pembelajaran tematik integratif sudah mencapai kategori baik sejak siklus 1. Hasil observasi pada penampilan guru meningkat pada siklus 2 sebesar 9,50 poin, dan pada siklus 3 meningkat sebesar 9,17 poin. Rata-rata hasil observasi terhadap penampilan guru pada siklus 3 adalah 179,17 dengan kategori baik. Penampilan guru yang berada pada klasifikasi baik akan mendukung peningkatan motivasi belajar dan keterampilan hitung peserta didik.

Meningkatkan motivasi belajar peserta didik

Hasil pengamatan terhadap motivasi peserta didik dalam pembelajaran pada akhir siklus 3 mencapai skor 68,16 dengan klasifikasi baik. Hasil tes skala motivasi peserta didik dari siklus 3 memperoleh rata-rata skor total 87,05 dengan klasifikasi sangat tinggi. Pada akhir siklus 3 hasil tes skala motivasi semua peserta didik telah mencapai skor dengan kategori sangat tinggi. Peningkatan motivasi peserta didik dalam pembelajaran terjadi karena peserta didik tertarik dan terlibat langsung dengan penggunaan media papan pecahan desimal dan kartu bergambar dalam pembelajaran.

Meningkatkan Keterampilan Hitung Penjumlahan dan Pengurangan pada Pecahan desimal

Hasil tes keterampilan hitung peserta didik telah memenuhi kriteria keberhasilan dalam penelitian ini. Peningkatan keterampilan hitung penjumlahan dan pengurangan pecahan desimal peserta didik terjadi karena selain guru menggunakan media manipulatif, juga karena guru berusaha memancing peserta didik untuk memahami hubungan antara operasi penjumlahan dan pengurangan dalam proses pembelajaran.

\section{Saran}

Saran yang disampaikan adalah sebagai berikut: (1) guru dapat menggunakan media manipulatif yang ada dalam penelitian ini agar tujuan pembelajaran dapat tercapai dan dapat meningkatkan motivasi belajar bagi peserta didik; (2) Penilaian keterampilan hitung dalam penelitian ini hanya menggunakan penilaian jika jawaban peserta didik salah karena kurang teliti sama nilainya dengan peserta didik yang jawabannya asal-asalan maka peneliti selanjutnya dapat mengembangkan rubrik penilaian dengan lebih baik agar penilaiannya tidak merugikan peserta didik dan menghasilkan data yang lebih baik.

\section{DAFTAR PUSTAKA}

Adeyemi, D. A. (2010). Justification of a multidisciplinary approach to teaching language in botswana junior secondary scholls. The Journal of Language, technology \& Enterpreneurship in Africa, vol 2, 1, 2010.

Ayres, H. W. (2005). Factors related to motivation to learn and motivation to transfer learning in a nursing population. (Disertasi doktor, North Carolina State University, 2005). UMI, 3162411.

Bangurah, K. H. E. (2007). The efficacy of manipulative material for improving the academic achievement and attitudes of atrisk middle school students. (Disertasi doktor, American University, 2007)

Bennet, A.B., Jr, Burton, L.J., \& Nelson, L.T. (2012). Mathematics for elementary teachers: a conceptual approach. New York: The Mc Graw Hill Company.

Blaszczynzki, C., \& James, M. L. (2001). Fractions, and decimals, and percents, oh my! Proceeding of the Academy of Educational Leadership, vol. 6, 2, 19-24.

Burns. (2013). Improving student achievement in mathematics by using manipulatives with classroom instruction. The Natonal Council of Supervisors of Mathematics Improving Student Achievement Series, 11.

Carroll, W.M. (1996). Mental computation of students in a reform-based mathematics curriculum. School Science and 


\section{Jurnal Riset Pendidikan Matematika, 3 (1), Mei 2016 - 135 \\ Yuni Ristanti}

Mathematics. Oct 1996; 96, 6; ProQuest. pg. 305.

Cook, S. P. (2009). Making connections: implementing an integrated thematic Instruction curriculum model to assist teachers of at-risk Middle school students. (Disertasi Doktor, Rowan University, 2009). UMI, 3359922.

D'Augustine, C. \& Smith, C.W. (1992). Teaching elementary school mathematics. Boston, Massachusetts: HarperCollins Publisher Inc.

Daryanto. (2013). Media pembelajaran: peranannya sangat penting dalam mencapai tujuan pembelajaran. Yogyakarta: Gava Media.

Degeng, N. S. (2013). Ilmu pembelajaran: klasifikasi variabel untuk pengembangan teori dan penelitian. Bandung: Aras Media.

Mardapi, D. (2008). Teknik penyusunan instrumen tes dan nontes. Jogjakarta: Mitra Cendikia Press.

Djohar. (2006). Guru, pendidikan \& pembinaannya (penerapannya dalam pendidikan dan UU guru). Yogyakarta: CV Grafika Indah.

Durmuş S. \& Karakirik, E. (2006). Virtual manipulatives in mathematics education: a theoretical framework. The Turkish Online Journal of Educational Technology, 5,117-123.

Widoyoko, E. P. (2013). Evaluasi Program Pembelajaran. FKIP UNS Surakarta: Surakarta.

Humaida, I. A.I. (2012). Research on: Motivation to Learn English among College Students in Sudan. English Language Teaching; Vol. 5, 49-56.

Ahmadi, I. K., \& Amri, S. (2014). Pengembangan \& model pembelajaran tematik integratif. Jakarta: Prestasi Pustaka.

McCharty, P. (2007). The role of mental computation and estimation in elementary school. (Disertasi Doktor, University of Toronto, 2007). Library and Archives Canada, 978-0-494-27929-8.
McTaggart, R. (1991). Action research: a short modern history. Victoria, Australia: Deakin University Press.

Menteri Pendidikan dan Kebudayaan. (2013). Peraturan Menteri Pendidikan Dan Kebudayaan Nomor 64, Tahun 2013, tentang standar Isi Pendidikan Dasar dan Menengah.

Menteri Pendidikan dan Kebudayaan. (2013). Peraturan Menteri Pendidikan Dan Kebudayaan Nomor 67, Tahun 2013, tentang Kerangka Dasar dan Struktur Kurikulum Skolah Dasar/Madrasah Ibtidaiyah.

Wangid, M., Mustadi, A., Erviana, V., \& Arifin, S. (2014). Kesiapan guru SD dalam pelaksanaan pembelajaran tematikintegratif pada kurikulum 2013 DI DIY. Jurnal Prima Edukasia, 2(2), 175182.

doi:http://dx.doi.org/10.21831/jpe.v2i2.27 17

Mun Yee Lai \& Kin Wai Tsang. (2009). Understanding primary children's thinking and misconceptions in decimal numbers. International Conference on Primary Education, 1-8.

Nilsen, H. (2009). Influence on student academic behaviour through motivation, self-efficacy and value- expectation: an action research project to improve learning. Issues in Informing Science and Information Technology, Vol. 6, 545-556.

Santrock, J. W. (2011). Educational psychology. New York: Mc Graw Hill.

Smaldino, S.E., Lowther, D.B., \& Russel, J.D. (2007). Instructional technology and media for learning.Upper Saddle River, United State of America: Pearson Merril Prentice Hall.

Souviney, R. J. (1994). Learning to teach mathematics (2nd ed.). New York: Macmillan Publishing Company.

Sud, A., \& Kumar, S. (2006). Dysfunctional thoughts, achievement motivation, and test anxiety among University students. Pakistan Journal of Psychological Reserch, 21, 1/2, 40-51; ProQuest Research Library. 
Sugiyono. (2013). Metode penelitian pendidikan: pendekatan kuantitatif, kualitatif, dan $r \& d$. Bandung: Alfabeta.

Wheeldon, D. A. (2008). Developing mathematical practices in a social context: an Instructional sequence to support prospective elementary teachers' learning of fractions. (Disertasi doktor, University of Central Florida, 2008). UMI, 3319284.

Witzel, B. S., Ferguson, C. J., \& Mink, D. V. (2012). Number sense: strategi for helping preschool through grade 3 children develop math skills. National Association for Education of Young Children, 5, 8994.
Woolfolk, A. E. (2007). Educational psychology. Boston, Massachusetts: Pearson Education, Inc.

Woolfolk, A. E., \& Nicolich, L. M. (1984). Educational psychology for teachers. Englewood Cliffs, New Jersey: PrenticeHall, Inc.

Yen Hua Chen, Chiu Pin Lin, Chee Kit Looi, Yin Juan Shao, Tak Wai Chan (2012). A collaborative cross number puzzle game to enhance elementary students' arithmetic skills. The Turkish Online Journal of Educational Technology, 11, 2, 1- 14. 